\title{
DOI 10.26886/2520-7474.4(36)2019.4
}

UDC: 159.923:159.942.5

\section{A HUMOR USE AS MULTIASPECT PHENOMENA}

\section{IN PSYCHOTHERAPY}

\section{Volzhentseva, Doctor of Psyhological Sciences, Professor, the Academician of Ukraine Technological Academy (UTA)}

Pereyaslav- Khmelnytskyi State Pedagogical University named after Hryhoriy Skovoroda», Ukraine, Pereyaslav- Khmelnytskyi

In the article a theoretical analysis of scientific literature on the humor use in psychotherapeutic practice is provided. The author's approach to the distribution of the use of regulation methods of the emotional sphere in psychotherapy is given. A humor is distinguished (gelotology) as a direct method of regulation which has a positive effect on human activity. The essence of the phenomenon "humor" under the different types of psychotherapy, such as rational-emotional-behavioral, psychoanalysis, body-oriented psychotherapy, as well as the use of humor in different techniques, such as yoga-laughter, hospital clownery, etc is revealed. The polyfunctionality of humor is characterized taking into account interscientific approaches, which makes it possible to present the overall complex structure of the humor use as a multidimensional phenomenon in psychotherapy, which includes psychological, psycholinguistic, medical, physiological, psychological-pedagogical, game, diagnostic aspects.

Keywords: humor, psychotherapy, gelotology, laughter, methods of regulation, multifunctionality of humor, the multiaspect of humor.

доктор психологічних наук, профресор, академік Української технологічної академії (УТА), Волженцева І. В. Використання гумору як багатоаспектного явища в психотерапії/ Переяслав- 
Хмельницький державний педагогічний університет імені Григорія Сковороди, Україна, Переяслав-Хмельницький

У статті проводиться теоретичний аналіз наукової літератури з проблеми використання гумору у психотерапевтичній практиці. Подано авторській підхід до розподілу використання методів регуляції емоційної сфери у психотерапії. Виокремлено гумор (гелотологія) як безпосередній метод регуляції, який позитивно впливає на життєдіяльність людини. Розкрито сутність френомену «гумор» в рамках різних видів психотерапії, таких як раціональноемоційно-поведінкова, психоаналіз, тілесно-орієнтована психотерапія, а також використання гумору в різних техніках, таких як йога-сміху, лікарняна клоунада та ін. Охарактеризовано поліфрункціональність гумору з урахуванням міжнаукових підходів, що дає можливість представити загальну комплексну структуру використання гумору як багатоаспектного явища в психотерапії, що включає психологічний, психолінгвістичний, медичний, фрізіологічний, психолого-педагогічний, ігровий, діагностичний аспекти.

Ключові слова: гумор, психотерапія, гелотологія, сміх, методи регуляції, поліфункціональність гумору, багатоаспектність гумору.

Постановка проблеми. Проблема емоційної сфери у вітчизняній та зарубіжній психологічній науці має важливе практичне значення, оскільки розуміння власних емоційних станів і вміння регулювати їх, дозволяє поліпшити ефективність будь-якої людської діяльності, уникнути безліч стресогенних ситуацій або пом'якшити їх вплив і розв'язати з найменшими втратами для себе.

У психологічній науці методам регуляції і саморегуляції присвячена велика кількість робіт таких авторів як: А. В. Алексеєв, В. А. Бодров, Г. Ш. Габдреєа, Л. П. Гримак, Л. Г. Дікая, В. І. Єдокимов, 
К. Ізард, Е. П. Ильїн, Х. Лідеман, В. С. Лобзін, В. Л. Марищук, В. М. Панкратов, О. О. Прохоров, І. Г. Шульц та ін. Проведений аналіз показав, що проблема регуляції належить до фундаментальних проблем психології і як самостійна психологічна категорія являє собою сукупність процесів коригувального, координаційного й інтегрувального впливу на психіку, нервову систему й гуморальні чинники, що забезпечують динамічну рівновагу в конкретних умовах життєдіяльності й поведінки людини (Б. Г. Ананьєв, Л. С. Виготський,

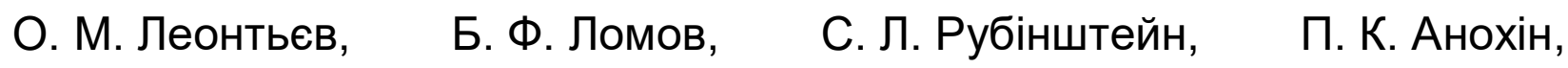
Г. Ш. Габдреєва, О.О.Конопкін). Саморегуляція проявляється як процес цілеспрямованої зміни психічних станів і психофрізіологічних функцій, управління людиною своїми емоціями, відчуттями і переживаннями, свідомий вибір характеру і способу дій, «внутрішня» регуляція поведінкової активності людини (В.І. Моросанова, О. Я. Чебикін).

Існуючі методи регуляції Е. П. Ільїн [9] поділив на дві групи: зовнішні (фрармакологічні, зовнішнє навіювання, гіпноз, музикотерапія, фрізичні засоби (масаж, гідропроцедури, акупунктура) і внутрішні (саморегуляція). Проте автор рахує цей розподіл умовним, оскільки навіювання може бути і самонавіянням, а масаж - і самомасажем і т. п.

Інший підхід пропонує К. Ізард [8], який виділяє три методи усунення небажаного емоційного стану:

регуляція за допомогою іншої емоції, тобто припускає необхідність свідомих зусиль, спрямованих на активацію іншої емоції, протилежної до тієї, яку людина переживає і хоче усунути; когнітивна регуляція, яка пов'язана з використанням уваги і мислення для пригнічення небажаної емоції або встановлення контролю над нею. Це перемикання свідомості на події і 
діяльність, що викликають у людини інтерес, позитивні емоційні переживання;

моторна регуляція, припускає використання фрізичної активності як каналу розрядки виниклої емоційної напруги [3].

Теоретичний аналіз наукової літератури, емпіричні фракти досліджень показали недостатність розробленості й використання гумору в емоційній сфрері.

Mema cmammi - розкрити сутність френомену гумор як методу регуляції емоційної сфрери, як багатоаспектного явища в психотерапії.

Виклад основного матеріалу. В основу розподілу методів емоційної регуляції в психотерапії (див. рис. 1) нами було покладено дихотомічний принцип. Така полярність у відборі і застосуванні основних методів регуляції забезпечує чітку методичну і методологічну базу переходу від теоретичного їх обґрунтування до застосування в психотерапевтичній практиці. Виходячи з дихотомічного відбору методів регуляції, ми зупинилися на двох полярних: безпосередніх і опосередкованих. Не дивлячись на те, що їх основне завдання - це регуляція емоційних станів суб'єкта, засоби реалізації цього завдання різні [3].

До опосередкованих методів регуляції ми відносимо методи, реалізація яких припускає спеціально організоване дослідницьке або терапевтичне середовище з використанням спеціального обладнання, приладів, різних предметів і об'єктів фрізичного світу, сприяючих досягненню регулюючого ефекту, це регуляція через іншу людину, що припускає урахування початкових даних суб'єкта на момент процедури, стійких його індивідуально-особистісних, динамічних характеристик.

Складність цих методів регуляції, на наш погляд, полягає в тому, що їх ефрективність безпосередньо залежить від індивідуальних особливостей суб'єкта [3]. Незважаючи на дихотомічний розподіл 
методів регуляції, у зв'язку із застосуванням зовнішніх предметів фрізичного середовища, опосередковані методи в нашому дослідженні розподіляються на активні і пасивні.

\begin{tabular}{|c|c|c|}
\hline \multicolumn{3}{|c|}{ Методи регуляції емоційних станів } \\
\hline безпосередні & \multicolumn{2}{|c|}{ опосередковані } \\
\hline 7 & & 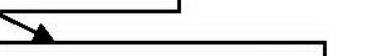 \\
\hline \multirow{15}{*}{$\begin{array}{l}\text { - ароматерапія (масла) } \\
\text { - фітотерапія (рослини) } \\
\text { - квіткова терапія } \\
\text { - кольоротерапія } \\
\text { - музикотерапія } \\
\text { - вокалотерапія } \\
\text { - біозвукотерапія } \\
\text { - бібліотерапія } \\
\text { - казкотерапія } \\
\text { - кінотерапія } \\
\text { - катарсичний } \\
\text { - гелотологія (гумор) } \\
\text { - дихальна гімнастика } \\
\text { - самомасаж } \\
\text { - аутотренінг } \\
\text { - медитація }\end{array}$} & активні & пасивні \\
\hline & 7 & \pm \\
\hline & - імаготерапія & - гідротерапія \\
\hline & - працетерапія & - акупунктура \\
\hline & - імітаційні ігри & - рефлексотерапія \\
\hline & - пісочна терапия & - сугестія \\
\hline & - танцетерапія & (навіювання ) \\
\hline & - масаж & - гетеротпенінг \\
\hline & & - фармакотерапія \\
\hline & & - слайдотерапія \\
\hline & & - відеотерапія \\
\hline & & - бінауральна \\
\hline & & звукотерапія \\
\hline & & \\
\hline & & \\
\hline
\end{tabular}

Рис. 1. Розподіл методів регуляції емоційної сфери у психотерапії

До активних опосередкованих методів регуляції ми відносимо ті, які пов'язані з рухом i, за допомогою гіподинамії, максимально ефективно забезпечують фрізичну розрядку, регулюючи психічні стани представників конкретних типологічних груп 3 використанням зовнішніх подразників, предметів і об'єктів фрізичного світу: камінь, пісок, інші люди і так далі. До таких методів регуляції ми відносимо пісочну терапію, танцетерапію та ін.

До пасивних опосередкованих методів регуляції ми відносимо більш інертні, спокійні методи регуляції, в них елементи руху, фізичного навантаження будуть у меншій мірі, але вони теж 
опосередковані, тому що використовують допоміжні предмети, інструменти, речовини, нейтральні фрармакотерапевтичні засоби природного і штучного походження: вода, слово, звук та ін. До таких методів регуляції ми відносимо: гідротерапію, рефлексотерапію, бінауральні звуки та ін. [3].

До безпосередніх методів регуляції ми відносимо методи, що припускають регуляцію психічних станів без спеціальної підготовки, іноді спонтанно, за участю різних аналізаторів, таких як зоровий, слуховий, нюховий, дотиковий, які сприяють досягненню регулюючого ефректу без застосування яких-небудь предметів навколишнього світу. До цього методу регуляції ми відносимо: кольоротерапію, музикотерапію, ароматерапію, гелотологію та ін. (див. рис. 1).

На сучасному етапі саме гелотологія (від греч. gelos - сміх), яка досліджує вплив сміху на людський організм, заявила про себе як новий метод управління емоційними станами. Зародилася в 70-х роках в Америці, засновник гелотології Норман Казинс увійшов до історії як «людина, якій вдалося розсмішити смерть» [18]. Сміх - це особливий спосіб дихання, вдих подовжується і стає глибшим, а видих, навпаки, коротшає і стає інтенсивнішим, так що легені повністю звільняються від повітря. Кінцевий ефект сміху схожий 3 йогівською дихальною гімнастикою. Оптимізація дихання в процесі сміху різко покращує кровопостачання органів і тканин, нормалізує артеріальний тиск, автоматично покращується самопочуття людини, його настрій [3; 18].

Сутність методу гелотологія та його психолінгвосинонімічний зв'язок зі сміхотерапією, гуморотерапією підкреслює велике практичне значення цього френомену в психотерапії - системі лікувального впливу на психіку і через психіку на організм людини для позбавлення від різних проблем (емоційних, особистісних, соціальних, і т. п.). 
Саме раціонально-емоційно-поведінкова терапія (РЕПТ), підхід в психотерапії, створений Альбертом Еллісом в 1955 році, націлена на навчання клієнтів самодопомоги, раціональної поведінці в проблемних ситуаціях, використовуючи такі терапевтичні методи, як: дискусія (спростування) ірраціональних ідей; бібліотерапія (читання матеріалів, книг з самодопомоги); семантичні методи; емоційна установка на безумовне прийняття; поводитися так, як ніби клієнт вже мислить раціонально; гумористичні методи, які ґрунтуються на сатиричногумористичних жанрах, таких як: усмішки, гостроти, гуморески, жарти, співомовки, спонтанний гумор та ін.

Гумор як прийом використовується і в провокаційній терапії Ф. Фарреллі (приховано-агресивні жарти, провокації, абсурд, перевизначення) [21]; логотерапії В. Франкла (парадоксальна інтенція терапія «від противного», відповідно до якої індивіда заохочують 3 відповідним гумором); у психоаналізі 3. Фрейда (сміх як позбавлення від зайвої нервової енергії) [21]; у тілесно-орієнтованій психотерапії [17]; ігротерапії, бібліотерапії. Також застосування гумору має місце в різних техніках, таких як: йога-сміху (хасья-йога), лікарняна клоунада [6], клуби і кімнати сміху, лікування соматичних пацієнтів (вплив сміху на імунітет, біль, довголіття) [1], клінічна психотерапія неврозів [16], сміхотерапія в педагогіці [13], гумор на робочому місці (тренінги у вигляді гумористичних практичних занять) [12], ведення гумористичних щоденників, гумор в позитивній і популярній психології [14; 15].

На думку Р. Мартіна, одним із механізмів регулювання емоцій виступає саме гумор, який може викликати посилення позитивних відчуттів, послаблювати ступінь прояву негативних відчуттів, допомагаючи індивіду успішно долати тривогу, напруження, гнів, стрес (наводиться за: [2, с. 15]). 
Так як гумор сприяє виникненню сміху, Е. П. Ільїн відмічає, що він робить різноманітний позитивний вплив на психічні і фрізіологічні процеси, пригнічує біль, оскільки під час сміху вивільняються гормони катехоламіни і ендорфіни. Перші перешкоджають запаленню, другі діють як морфін. Позитивний вплив сміху зберігається протягом доби. Автором відмічено позитивний вплив сміху на склад крові. Сміх зменшує стрес і його наслідки, знижуючи концентрацію стресових гормонів - норепінефрину, кортизолу і допаміну [9].

Гумор дає можливість проявитися емоціям, які повідомляють, попереджають, інфрормують, підказують про щось погане чи хороше. Він допомагає людині побачити і відкрити для себе різні безглуздості життя і життєвих ситуацій, що нормалізує самопочуття (фізичне і емоційне), направляє до вищого рівня вирішення проблеми, збільшує пізнавальний потенціал, духовно збагачує. Була запропонована модель, що описує психологічні функції позитивної емоції, - радощі [25; 26].

Аналіз вітчизняних і зарубіжних психологів дозволив розглянути феномен гумору багатоаспектно, комплексно, поліфункціонально, 3 урахуванням міжнаукових, міждисциплінарних підходів й представити загальну комплексну структуру впливу гумору на життєдіяльність особистості, яка включає психологічний, психолінгвістичний, медичний, фрізіологічний, психолого-педагогічний, ігровий, діагностичний аспекти (див. рис. 2).

Так, психологічний аспект використання гумору розкривається в питаннях набутті навичок міжособистісної комунікації (поліпшення взаємин у групі, міжособистісних стосунків, корекція антисоціальних моделей поведінки, запобігання конфліктів і примирення сторін; визнання наявності розбіжностей близьких людей; об'єднання при спільній діяльність); емоційної сфери (подолання тривожності, 


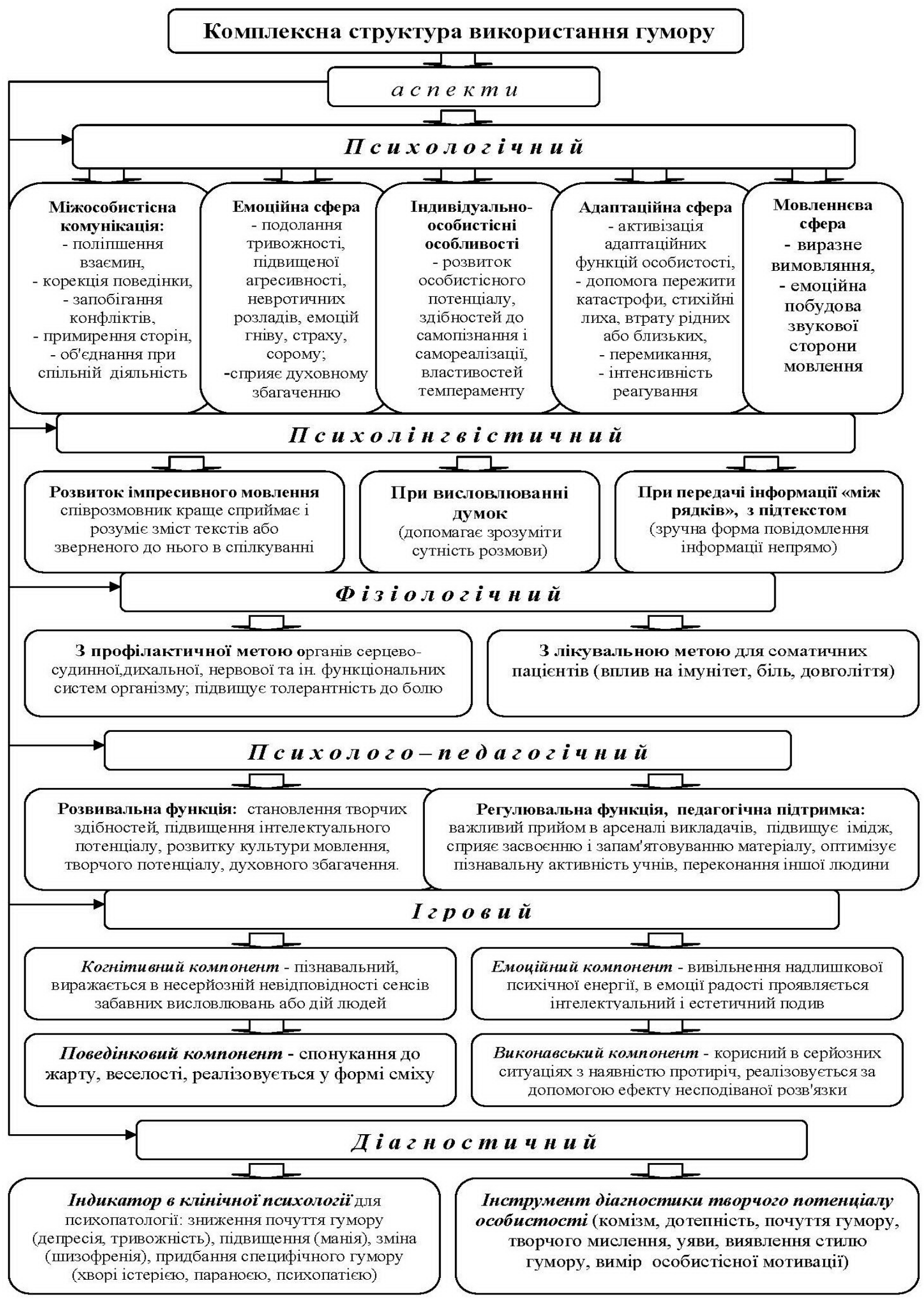

\section{Рис. 2. Загальна комплексна структура використання гумору як багатоаспектного явища в психотерапії}


підвищеної агресивності, невротичних розладів; звільнення глибоко репресованих емоцій гніву, страху сорому; сприяє духовному збагаченню); в дослідженні індивідуально-особистісних особливостей (розвиток особистісного потенціалу, здібностей до самопізнання і самореалізації, властивостей темпераменту ( $у$ сангвініків теплий гумор, меланхоліки схильні до теплої іронії, холерикам ближче сатира, фрлегматикам - сарказм, уїдлива іронія); адаптаційного аспекту (активізація адаптаційних фрункцій особистості (допомога пережити катастрофри, стихійні лиха, втрату рідних або близьких), перемикання, інтенсивність реагування; мовленнєвої сорери (виразне вимовляння, емоційна побудова звукової сторони мовлення)

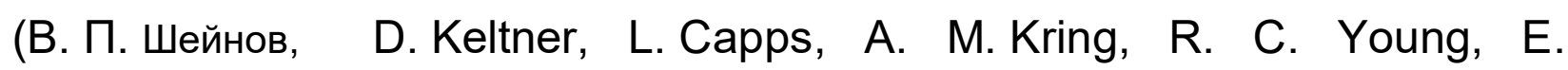
A. Heerey) [20; 22].

У межах психолінгвістичного аспекту можливості гумору необхідні в разі розвитку імпресивного мовлення (співрозмовник краще сприймає і розуміє зміст текстів або зверненого до нього в спілкуванні); при висловлюванні думок (допомагає зрозуміти сутність розмови); при передачі інформації «між рядків», з підтекстом (прихований вплив на слухачів, зручна фрорма повідомлення інфрормації непрямо, а за допомогою натяків) (M. Mulkay) [23].

У фрізіологічному аспекті позитивний вплив гумору стає вкрай потрібним з профрілактичною метою органів серцево-судинної, дихальної, нервової та інших функціональних систем організму; 3 лікувальною метою для соматичних пацієнтів (вплив на імунітет, біль, довголіття); підвищує толерантність до болю $(\mathrm{H}$. Казинс, С. Н. Назаркин, А. Е. Фокина, А. В. Скутин, І. Н. Мороз) [1; 16; 19].

Психолого-педагогічний аспект використання гумору відображається в двох напрямах: розвивальному і регулювальному. Так, в розвивальному - це питання становлення творчих здібностей, 
підвищення інтелектуальної сфери, розвитку культури мовлення, творчого потенціалу, духовного збагачення, в регулювальному - в процесі навчання - гумор дуже важливий прийом в арсеналі викладачів, учителів, як педагогічна підтримка, підвищення їхнього іміджу, сприяє засвоєнню і запам'ятовуванню матеріалу, оптимізує пізнавальну активність учнів до теми, що вивчається. Нерідко кепкування як агресивна фрорма гумору використовуються при переконанні однією людиною іншої, для примусу до тих або інших дій (Н. Р. Салимов) [14].

Іаровий аспект використання гумору припускає гру 3 невідповідностями і одночасно передає різні сенси; особливо корисний в ситуаціях, де серйозний, прямий спосіб обговорення може посилити наявні протиріччя. Ігрова поведінка - це вивільнення надлишкової психічної енергії, викликане інтелектуальним і естетичним подивом, це спонукання до жарту, веселості, $€$ необхідною умовою наявності позитивних емоцій, чуттєвості (сентиментальності).

Так, В. П. Шейнов визначає гумор як специфрічну гру, що включає чотири компоненти: когнітивний (пізнавальний, виражається в несерйозній невідповідності сенсів забавних висловлювань або дій людей); емоційний (проявляється в емоції радості); поведінковий (реалізовується у фрормі сміху); виконавський (реалізовується за допомогою ефекту несподіваності, несподіваної розв'язки). Автор підкреслює, що чим гра несподіваніша, тим сильніше проявляються усі компоненти гумору: несерйозна невідповідність, радість, сміх $i$ несподіваність [19].

Діагностичний аспект використання гумору представлено в двох напрямах: як індикатор в клінічної психології для виявлення порушень при різних видах психопатології: зниження почуття гумору (депресія, тривожність), підвищення (манія), зміна (шизофренія), придбання 
специфічного гумору (хворі істерією, параноєю, психопатією) [12], алкогольний гумор [5] та як інструмент діагностики творчого потенціалу особистості (комізм, дотепність, почуття гумору, творчого мислення, творчої уяви, виявлення стилю гумору, вимір особистісної мотивації тощо) для подальшого його розвитку.

Висновки. Таким чином, теоретичний аналіз наукової літератури 3 проблеми використання гумору у психотерапевтичній практиці показав багатогранність, поліфункціональність цього явища. Представлено авторській підхід з опорою на дихотомічний принцип відбору методів регуляції емоційної сфрери у психотерапії (безпосередні й опосередковані), в якому виокремлено гумор (гелотологія) як безпосередній метод регуляції, який позитивно впливає на життєдіяльність людини. Сутність методу гелотологія та його психолінгвосинонімічний зв'язок зі сміхотерапією, гуморотерапією підкреслює велике практичне значення цього феномену в психотерапії - системі лікувального впливу на психіку і через психіку на організм людини для позбавлення від різних проблем (емоційних, особистісних, соціальних, і т. п.).

Виокремлено гумористичні засоби впливу на особистість, які ґрунтуються на сатирично-гумористичних жанрах, таких як: усмішки, гостроти, спонтанний гумор, гуморески, жарти, співомовки та ін. Сутність френомену «гумор» охарактеризовано в рамках різних видів психотерапії, таких як раціонально-емоційно-поведінкова, психоаналіз, тілесно-орієнтована психотерапія, а також розкрито використання гумору в різних техніках, таких як йога-сміху, лікарняна клоунада та ін. Поліфункціональність гумору дало можливість представити загальну комплексну структуру використання гумору як багатоаспектного явища в психотерапії, що включає психологічний, психолінгвістичний, медичний, фрізіологічний, психолого-педагогічний, ігровий, 
діагностичний аспекти. Різноманітній досвід застосування гумору дослідниками з різних галузей знань дав цілісне уявлення щодо його широких, комплексних, багатогранних можливостей позитивного ефекту не тільки в організації поведінки людини, задоволенні її певних потреб, а також і в діагностиці творчого потенціалу особистості для подальшого його розвитку.

Перспективами подальших досліджень $\epsilon$ експериментальне вивчення особливостей впливу гумору на емоційну сферу особистості як корекційного засобу в стресогенних ситуаціях з урахуванням вікових і статевих відмінностей.

\section{Лumepamypa:}

1. Банников К. (2002) Смех и юмор в экстремальных группах (на примере некоторых аспектов доминантных отношений в современной Российской Армии), Смех, Истоки и функции, ред. А.Г. Козинцев. СПб., Наука, с. 174-186.

2. Волженцева И. В. (2012) Методологические и теоретикоэмпирические исследования полифуункциональной регуляции психических состояний личности эмоциогенными способами, Макеевский экономико-гуманитарный институт. Макеевка, МЭГИ, Донецк, Донбасс. 536 с.

3. Гурьева Е. С., Сулейманов Р. Ф., Гурьева Е. С. (2019) Больничный клоун. Казанский инновационный университет имени В. Г. Тимирясова. Казань: Познание, 95 с.

4. Домбровская И. С. (2011) Юмор в контексте психологической практики, Консультативная психология и психотерапия. № 1, С. 95108

5. Дурманова Т. Ю., Мазаилова Т. А. (2017) Технология больничной клоунады как направление развития молодежных добровольческих 
инициатив (на примере Алтайского края), Сборнике трудов конфреренции Молодёжь в меняющемся мире: вызовы современности, Уральский государственный педагогический университет (Екатеринбург). С. 44-49.

6. Иванова Е. М., Ениколопов С.Н. (2009) Психопатология и чувство юмора, Современная терапия психических расстройств. № 1, С. 1924.

7. Изард К. (2000) Психология эмоций. СПб, 464 с.

8. Ильин Е. П. (2005) Психофизиология состояний человека. СПб., Питер, 412 c.

9. Казинс Н. (1991) Анатомия болезни с точки зрения пациента. Размышления о лечении и выздоровлении, [Пер. с англ.]; [Предисл. Н. М. Амосова]. М., Физкультура и спорт. 95 с.

10. Мусийчук М.В.(2017) Юмор в психотерапии и консультировании: проблемы и решения в современных парадигмах, Медицинская психология в России, электрон. науч. журн. Т. 9, № 3(44).

11. Назаркин С. Н., Фокина А. Е. (2016) Юмор как средство совладания онкологических больных, Международный журнал гуманитарных и естественных наук. Т. 2. № 1, С. 107-109

12. Род Мартин (2009) Психология юмора. Пер. с англ. под ред. Л. В. Куликова. Москва, Питер. 478 с.

13. Салимов Н.Р. (2009) Формирование готовности будущего учителя к предупреждению и разрешению конфрликтов в школе средствами юмора: диссертация ... кандидата педагогических наук : 13.00.08, Салимов Наиль Раилевич; Башкир. гос. пед. ун-т. Уфа.

14. Селигман Мартин Новая позитивная психология (2006), [научный взгляд на счастье и смысл жизни]; [пер. с англ. под ред. И. Солухи]. Москва; Киев, София, 2006. 367 с. 
15. Свияш А., Свияш Ю. (2011) Улыбнись, пока не поздно!: позитивная психология для повседневной жизни. Москва, АСТ. 365 с.

16. Скутин А. В., Мороз И.Н. (2015) Включение гелототерапии в комплексную реабилитацию пациентов с невротическими расстройствами, Medline.ru. T. 16. № 4, С. 1151-1160.

17. Умярова Р. С. (2008) Смехотерапия, Консультативная психология и психотерапия. № 1.

18. Хотите быть здоровой? Тогда улыбайтесь, смейтесь и хохочите! [Электронный рсурс]. Режим доступа ttp: www.casualife.kiev.ua/index. php?name=News\&op=article\&sid=4730.

19. Шейнов В. П. Юмор как способ влияния [Электронный рсурс]. Режим доступа https://psy.wikireading.ru/103891

20. Шейнов В.П. (2007) Психологическое влияние (2-е изд.). Минск, Харвест. 638 с.

21. Щербинина О. В., Лобзина А.Р.(2016) Провокационная психотерапия в психологии управления: мотивирование персонала, Развитие профрессионализма. № 1, С. 220-221.

22. Keltner D., Capps L., Kring A. M., Young R. C, Heerey E. A. (2001) Just teasing: A conceptual analysis and empirical review. Psychological Bulletin. 127(2). 229-248.

23. Mulkay M. (1988) On humor: Its nature and its place in modern society. NewYork: Basil Blackwell.

24. Franzini L. R. (2001). Humor in therapy: the case for training therapists in its uses and risks. Journal of General Psychology, 128(2), 170-193.

25. Fredrickson B. L. (2001) The role of positive emotions in positive psychology: The broaden-and-build theory of positive emotions. American Psychologist. 55(3), 218-226.

26. Fredrickson B. L. (1998) What good are positive emotions? Review of General Psychology. 2 (3), 300 - 319. 


\section{References:}

1. Bannikov K. (2002) Smeh i jumor v jekstremal'nyh gruppah (na primere nekotoryh aspektov dominantnyh otnoshenij $v$ sovremennoj Rossijskoj Armii) [Laughter and humor in the extreme groups (for example, some aspects of the dominant relations in the modern Russian Army)], Smeh, Istoki i funkcii [Laughter: Origin and function], red. A.G. Kozincev. SaintPetersburg: Nauka, s. 174-186. [in Russian].

2. Volzhenceva I. V. (2012) Metodologicheskie i teoretiko-jempiricheskie issledovanija polifunkcional'noj reguljacii psihicheskih sostojanij lichnosti jemociogennymi sposobami [Methodological and theoretical-empirical reserches of multifunctional regulation of mental States of personality by emotional methods: monograph], Makeevskij jekonomiko-gumanitarnyj institut. Makeevka: MEGI, Donetsk, Donbass, 536 s. [in Ukrainian].

3. Gur'eva E. S., Sulejmanov R. F., Gur'eva E. S. (2019) Bol'nichnyj kloun_[Hospital clown]. Kazanskij innovacionnyj universitet imeni V. G. Timirjasova [Kazan innovative University named V. G. Timiryasova]. Kazan, Poznanie, 95 s. [in Russian].

4. Dombrovskaja I. S. (2011) Jumor v kontekste psihologicheskoj praktiki [Humor in the context of psychological practice], Advisory psychology and psychotherapy [Konsul'tativnaja psihologija i psihoterapija], № 1. S. 95-108. [in Russian].

5. Durmanova T. Ju., Mazailova T. A. (2017) Tehnologija bol'nichnoj klounady kak napravlenie razvitija molodezhnyh dobrovol'cheskih iniciativ (na primere Altajskogo kraja) [The technology of hospital clowning as a direction of development of youth volunteer initiatives (on the example of the Altai territory), Sbornike trudov konferencii Molodjozh' $v$ menjajushhemsja mire: vyzovy sovremennosti, Ural'skij gosudarstvennyj pedagogicheskij universitet [proceedings of the conference Youth in a 
changing world: challenges of our time, Ural state pedagogical University] Yekaterinburg, s. 44-49. [in Russian].

6. Ivanova E. M., Enikolopov S. N. (2009) Psihopatologija i chuvstvo jumora [Psychopathology and sense of humor], Sovremennaja terapija psihicheskih rasstrojstv [Modern therapy of mental disorders]. № 1. S. 1924. [in Russian].

7. Izard K. (2000) Psihologija jemocij_Psychology of emotions]. SaintPetersburg, 464 s. [in Russian].

8. Il'in E. P. (2005) Psihofiziologija sostojanij cheloveka_Psychophysiology of human states].Saint-Petersburg, Piter, 412 s. [in Russian].

9. Kazins Norman (1991) Anatomija bolezni s tochki zrenija pacienta [Anatomy of the disease from the patient's perspective]. Razmyshlenija o lechenii i vyzdorovlenii [Reflections on treatment and recovery], [Per. $s$ angl.]. [Predisl. N. M. Amosova]. Moscow, Fizkul'tura i sport. 95 s. [in Russian].

10. Musijchuk M. V. (2017) Jumor v psihoterapii i konsul'tirovanii: problemy i reshenija $v$ sovremennyh paradigmah [Humor in psychotherapy and counseling: problems and solutions in modern paradigms], Medicinskaja psihologija v Rossii, jelektron. nauch. zhurn_Medical psychology in Russia: electronic scientific journal]. T. 9. № 3(44). [in Russian].

11. Nazarkin S. N., Fokina A. E. (2016) Jumor kak sredstvo sovladanija onkologicheskih bol'nyh [Humor as a means of coping with cancer patients], Mezhdunarodnyj zhurnal gumanitarnyh i estestvennyh nauk_IInternational journal of Humanities and natural Sciences]. T. 2. № 1. S. 107-109. [in Russian].

12. Rod Martin (2009) Psihologija jumora_[Psychology of humor]. Per. S angl. pod red. L. V. Kulikova. Moskva: Piter. 478 s. [in Russian].

13. Salimov N. R. (2009) Formirovanie gotovnosti budushhego uchitelja k preduprezhdeniju $i$ razresheniju konfliktov $v$ shkole sredstvami jumora 
[Formation of the future teacher's readiness for the prevention and resolution of conflicts at school by means of humor]: dissertacija ...kandidata pedagogicheskih nauk: [thesis...candidate of pedagogical Sciences], Salimov Nail' Railevich; Bashkir. gos. ped. un-t. Ufa.[in Russian]. 14. Seligman Martin (2006) Novaja pozitivnaja psihologija, [nauchnyj vzgljad na schast'e $i$ smysl zhizni]_New positive psychology, [scientific view on happiness and meaning of life]; [per. s angl. pod red. I. Soluhi]. Moskva; Kiev: Sofia. 367 s. [in Russian].

15. Svijash A., Svijash Ju. (2011) Ulybnis', poka ne pozdno!,pozitivnaja psihologija dlja povsednevnoj zhizni_[Smile before it's too late! positive psychology for everyday life]._Moscow: AST. 365 s. [in Russian].

16. Skutin A. V., Moroz I. N. (2015) Vkljuchenie gelototerapii $v$ kompleksnuju reabilitaciju pacientov $s$ nevroticheskimi rasstrojstvami [The inclusion of gel therapy in the comprehensive rehabilitation of patients with neurotic disorders], Medline.ru. T. 16. № 4, S. 1151-1160. [in Russian].

17. Umjarova R. S. (2008) Smehoterapija [Laughter therapy], Konsul'tativnaja psihologija i psihoterapija_[Counseling psychology and psychotherapy]. № 1. [in Russian].

18. Hotite byt' zdorovoj? Togda ulybajtes', smejtes' i hohochite!_Want to be healthy? Then smile, laugh and laugh!] [Jelektronnyj rsurs]. Rezhim dostupa,

http:www.casualife.kiev.ua/index. php?name=News\&op=article\&sid=4730. [in Russian].

19. Shejnov V. P. Jumor kak sposob vlijanija [Humor as a way of influence] Rezhim dostupa: https:psy.wikireading.ru/103891 [in Russian].

20. Shejnov V. P. (2007) Psihologicheskoe vlijanie /Psychological influence] (2-e izd.). Minsk: Harvest, 638 s. [in Russian].

21. Shherbinina O. V., Lobzina A. R. (2016) Provokacionnaja psihoterapija v psihologii upravlenija: motivirovanie personala [Provocative 
psychotherapy in the psychology of management: motivation of personnel], Razvitie professionalizma [Development of professionalism]. № 1, S. 220221. [in Russian].

22. Keltner D., Capps L., Kring A. M., Young R. C, Heerey E. A. (2001) Just teasing: A conceptual analysis and empirical review. Psychological Bulletin. 127(2), 229-248. [in English].

23. Mulkay M. (1988) On humor: Its nature and its place in modern society. NewYork: Basil Blackwell. [USA].

24. Franzini L. R. (2001). Humor in therapy: the case for training therapists in its uses and risks. Journal of General Psychology, 128(2), 170-193. [in English].

25. Fredrickson B. L. (2001) The role of positive emotions in positive psychology: The broaden-and-build theory of positive emotions. American Psychologist. 55(3), 218-226. [USA].

26. Fredrickson B. L. (1998) What good are positive emotions? Review of General Psychology. 2(3), 300-319. [in English]. 